\title{
Article \\ Effects of Potassium Availability on Growth and Development of Barley Cultivars
}

\author{
Widad Al Azzawi ${ }^{2, \dagger}$, Muhammad Bilal Gill ${ }^{1,2, *}+{ }^{\dagger}$, Foad Fatehi ${ }^{2,3}$, Meixue Zhou ${ }^{2} \mathbb{D}$, Tina Acuña ${ }^{2}$, Lana Shabala ${ }^{2}$, \\ Min $\mathrm{Yu}^{1}$ and Sergey Shabala ${ }^{1,2, * \mathbb{D}}$
}

1 International Research Centre for Environmental Membrane Biology, Foshan University, Foshan 528000, China; yumin@fosu.edu.cn

2 Tasmanian Institute of Agriculture, College of Science and Engineering, University of Tasmania, Hobart, TAS 7005, Australia; widad.alshawi@utas.edu.au (W.A.A.); fatehi.foad@gmail.com (F.F.); meixue.zhou@utas.edu.au (M.Z.); tina.acuna@utas.edu.au (T.A.); 1.shabala@utas.edu.au (L.S.)

3 Department of Agriculture, Payame Noor University, Tehran 19395-4697, Iran

* Correspondence: muhammad.bilal@utas.edu.au (M.B.G.); sergey.shabala@utas.edu.au (S.S.)

+ Equal first author.

check for updates

Citation: Azzawi, W.A.; Gill, M.B.;

Fatehi, F.; Zhou, M.; Acuña, T.;

Shabala, L.; Yu, M.; Shabala, S. Effects of Potassium Availability on Growth and Development of Barley Cultivars. Agronomy 2021, 11, 2269. https:/ / doi.org/10.3390/agronomy11112269

Academic Editor: Borjana Arsova

Received: 24 September 2021

Accepted: 5 November 2021

Published: 10 November 2021

Publisher's Note: MDPI stays neutral with regard to jurisdictional claims in published maps and institutional affiliations.

Copyright: (c) 2021 by the authors. Licensee MDPI, Basel, Switzerland. This article is an open access article distributed under the terms and conditions of the Creative Commons Attribution (CC BY) license (https:/ / creativecommons.org/licenses/by/ $4.0 /)$.

\begin{abstract}
Potassium deficiency is one of the major issues affecting crop production around the globe. Giving the high cost of potassium fertilizers and environmental concerns related to inappropriate fertilization practices, developing more potassium use efficient (KUE) varieties is critical for sustainable food production in agricultural systems. In this study, we analysed the impact of potassium availability on agronomical attributes of thirty barley genotypes grown at four different levels of potassium $(0.002 \mathrm{mM}, 0.02 \mathrm{mM}, 2 \mathrm{mM}, 20 \mathrm{mM})$ under glasshouse conditions. The results showed that the availability of potassium in the soil had a major effect on yield components i.e., spike number, grain number and grain weight. Furthermore, grain weight showed a strong correlation with grain number and spike number at all levels of potassium supply. Although an increase in potassium supply led to an increase in plant height in all genotypes, the correlation with grain weight was very weak at all levels. Potassium supplementation caused an increase in shoot dry weight, which also showed a weak correlation with grain weight at the $0.002 \mathrm{mM}$ potassium supply level. The genotypes Gebeina, Skiff, YF374, Flagship and YF374 were highly efficient in performing at suboptimal K supply levels and, thus, can be recommended to be grown in K-impoverished soils. We also suggest that grain and spike numbers could be used as proxies for KUE studies, to construct DH lines and identify QTL to improve low potassium tolerance and KUE in barley.
\end{abstract}

Keywords: potassium use efficiency; genotypic variability; grain number; QTL

\section{Introduction}

Potassium $(\mathrm{K})$ is an essential macronutrient that plays an important role in the biochemical and biophysical processes of the plant, both at the cellular and whole-plant levels [1-3]. K significantly contributes to enzyme activation, metabolism, cell development, maintenance of membrane electric potential, protein synthesis, ionic homeostasis, cytosolic $\mathrm{pH}$ regulation, solute transport and cell turgor, particularly in the rapidly growing cells [4-6]. The availability of $\mathrm{K}$ affects the overall growth and development in plants and typically it can constitute up to almost 2-10 of the total plant dry matter [7]. The continuous supply of $\mathrm{K}$ is required by plants to maintain higher growth and development $[8,9]$. Most of the agricultural areas around the globe are reportedly deficient in available $\mathrm{K}$, including $75 \%$ of the rice paddy soils of China and more than $60 \%$ of the wheat belt in southern Australia $[10,11]$. The use of inorganic fertilisers in most parts of the world is very common to meet the nutritional requirements of plants.

The plant's requirements for $\mathrm{K}$ change during the growing season; seedling uptake is low and increases during the late vegetative and flowering stages [12,13]. A deficiency of 
$\mathrm{K}^{+}$may result in poor root growth, restricted leaf development, fewer grains per head and smaller grain size, all of which affect both yields quantitatively and qualitatively $[14,15]$. Although the levels of $\mathrm{K}$ in agricultural soils are relatively high, concentrations available to plants in the soil solution are often low (around 10-100 $\mu \mathrm{M}$ ). It is well documented that the supply of $\mathrm{K}$ to crops is a complex phenomenon and depends on many factors during the actual growing season. $\mathrm{K}^{+}$supply from the soil is often inadequate for profitable crop production and hence $\mathrm{K}^{+}$fertilizers must be supplied to crops for better growth and yield [16]. However, $\mathrm{K}^{+}$fertilizers are expensive and come with additional burden to farmers. This prompts a need to increase potassium use efficiently by crops by improving fertiliser management practices and/or selecting genotypes with higher potassium uptake and utilization efficiency $[17,18]$.

Currently one of the major challenges for agriculture is to enhance crop production in an economic and more environmentally friendly manner [19]. Two main solutions are the use of slow-release fertilisers and breeding genotypes that have a better ability to uptake and utilize K [20-22]. Slow-release fertilisers are expensive and not available to all farming communities. Therefore, selecting/breeding varieties that are capable to perform well at low $\mathrm{K}$ levels in the soil is the most effective approach. Two major issues hold the progress in this field. The first one is a high mobility of $\mathrm{K}^{+}$within a plant that "uncouples" root $\mathrm{K}^{+}$uptake and its translocation to the developing grain. Because of this, leaf $\mathrm{K}^{+}$content not always serves as a reliable indicator of KUE. The second issue is the lack of truly contrasting genotypes that can be used for constructing double haploid (DH) lines to be used for marker-assisted selection (MAS).

Barley (Hordeum vulgare L.) is an important cereal crop and ranked fourth in terms of planting area in the world, only after wheat, maize and rice [23]. Although barley shows a superior ability to cope with mineral nutrient deficiencies, under limited supply of $\mathrm{K}$ growth and yield of barley is significantly impacted [24,25]. This issue is becoming severe with modern high yielding genotypes. Over time, plants have developed different mechanisms to deal with low $\mathrm{K}$ availability. Plants have shown a great variation among species and genotypes within species in response to low K availability [26-28]. However, there is a limited genetic diversity in KUE in the present varieties of cultivated barley [29,30]. Thus, it is important to produce barley cultivars with greater diversity for low K by targeting more closely related traits to yield.

In this study, 30 barley genotypes were grown under conditions of various $\mathrm{K}$ supply-from extremely deficient $(2 \mu \mathrm{M})$ to optimal $(2 \mathrm{mM})$ and luxury $(20 \mathrm{mM})$ - and screened to find the best genetic material for developing barley genotypes with better potassium use efficiency. The results showed that the traits grain number and spike number showed a strong correlation with grain yield and thus can be used as proxy in genetic programs. Contrasting genotypes have been identified and recommended for creating mapping $\mathrm{DH}$ population, to reveal QTL responsible for potassium use efficiency in barley and incorporation into barely breeding programs.

\section{Materials and Methods}

\subsection{Genetic Material and Experimental Design}

Thirty barley (Hordeum vulgare L.) genotypes, originating from Australia, China, USA and Japan (Supplementary Table S1) were used to evaluate the phenotypic variation in $\mathrm{K}^{+}$efficiency in shoot growth and grain yield. The experiment was a randomized block design with 30 genotypes and four levels of $\mathrm{K}^{+}(0.002 \mathrm{mM}, 0.02 \mathrm{mM}, 2 \mathrm{mM}$, and $20 \mathrm{mM})$. All treatments were replicated six times.

Seeds were surface sanitized with $10 \%$ commercial bleach (NaClO $42 \mathrm{~g} \mathrm{~L}^{-1}$; Pental Products, Shepparton, Australia) for $10 \mathrm{~min}$, then thoroughly rinsed with tap water (for at least $30 \mathrm{~min}$ ), and then grown in the six-inch pots in a glasshouse at the University of Tasmania, Hobart, Australia. The pots were filled with coarse sand and vermiculite mix $(70: 30 \mathrm{v} / \mathrm{v})$. Ten seeds were planted in each pot and thinned to six plants per pot at a later 
stage. The day/night temperatures were $24 / 18^{\circ} \mathrm{C}$ with an average day length of $12 \mathrm{~h}$. Plants were watered daily with Hoagland solution with modified $\mathrm{K}^{+}$levels (Table 1 ). To control the potassium concentration of the nutrient solution, $\mathrm{KNO}_{3}$ was replaced with $\mathrm{NaNO}_{3}$, and $\mathrm{KH}_{2} \mathrm{PO}_{4}$ was replaced with $\mathrm{NH}_{4} \mathrm{H}_{2} \mathrm{PO}_{4}$. The four treatments of $\mathrm{K}$ at different concentrations $(0.002 \mathrm{mM}, 0.02 \mathrm{mM}, 2 \mathrm{mM}$, and $20 \mathrm{mM}$ ) were made by using $\mathrm{KCl}$. The $\mathrm{K}$ treatments were applied when plants reach to second fully expanded leaf. Throughout the experiment, the $\mathrm{pH}$ of the Hoagland solution was adjusted between 6-6.5.

Table 1. Composition of modified Hoagland solution used in experiment.

\begin{tabular}{lll}
\hline Component & Concentration & mL Stock/L \\
\hline $1 \mathrm{M} \mathrm{NaNO}_{3}$ & $85 \mathrm{~g} / \mathrm{L}$ & 5 \\
$1 \mathrm{M} \mathrm{Ca}\left(\mathrm{No}_{3}\right)_{2} \mathrm{H}_{2} \mathrm{O}$ & $236 \mathrm{~g} / \mathrm{L}$ & 5 \\
$1 \mathrm{M} \mathrm{MgSO}_{4}$ & $246.5 \mathrm{~g} / \mathrm{L}$ & 2 \\
$1 \mathrm{M} \mathrm{NH}_{4} \mathrm{H}_{2} \mathrm{PO}_{4}$ & $80 \mathrm{~g} / \mathrm{L}$ & 1 \\
$1 \mathrm{M} \mathrm{Fe}-\mathrm{EDTA}$ & $15 \mathrm{~g} / \mathrm{L}$ & 0.25 \\
$0.046 \mathrm{M} \mathrm{H}_{2} \mathrm{Bo}_{3}$ & $2.86 \mathrm{~g} / \mathrm{L}$ & 0.25 \\
$0.009 \mathrm{M} \mathrm{MnCl}_{2} \mathrm{H}_{2} \mathrm{O}$ & $1.81 \mathrm{~g} / \mathrm{L}$ & 0.25 \\
$7.65 \times 10^{-4} \mathrm{ZnSO}_{4} 7 \mathrm{H}_{2} \mathrm{O}$ & $0.22 \mathrm{~g} / \mathrm{L}$ & 0.25 \\
$3.2 \times 10^{-4} \mathrm{CuSO}_{4} 5 \mathrm{H}_{2} \mathrm{O}$ & $0.08 \mathrm{~g} / \mathrm{L}$ & 0.25 \\
$1.11 \times 10^{-4} \mathrm{H}_{2} \mathrm{MoO}_{4} \mathrm{H}_{2} \mathrm{O}$ & $0.02 \mathrm{~g} / \mathrm{L}$ & 0.25 \\
\hline
\end{tabular}

\subsection{Methods}

Prior to harvesting for biomass parameters, the number of spikes/plant were counted. At the time of harvesting, the plant shoots were cut $2-5 \mathrm{~cm}$ above the soil surface. After harvesting, the plant height $(\mathrm{cm})$ of randomly selected six plants per treatment was measured. The plant samples were collected in paper bags. The shoot dry weights were measured after drying in a Unitherm Drier (Birmingham, England) for 2 days at $65^{\circ} \mathrm{C}$. The spikes were kept for drying to collect the data for grain number and grain weight. The seeds were separated from the spikes and grain weights $(\mathrm{g})$ were measured. The number of seeds was counted by using the Contador seed counter (CE Pfeuffer), Baumann Saatzuchtbedarf, Waldenburg, Germany)

\subsection{Statistical Analysis}

The data analysis was subjected to correlation and variance using IBM SPSS Statistics. Average data for plant height, dry shoot weight, tiller number, spike number, grain number and grain weight for each of the four K treatments were grouped (G\#) using hierarchical cluster analysis (HCA) based on Euclidean distances as a measure of dissimilarity and Ward's method as a clustering algorithm using XLSTAT software (Addinsoft, New York, NY, USA). Principal component analysis (PCA) was performed using traits mean values with Kaiser's criterion (i.e., eigenvalue more than 1) using XLSTAT software. Fisher's Least Significant Difference (LSD) was calculated by using R (R Foundation, Vienna University of Economics and Business, Austria).

\section{Results}

\subsection{Cluster Analysis}

The results of the cluster analysis are presented in Figure 1 and show that the genotypes were classified into three groups based on agronomical traits. The three groups for genotypes were separated by the two principal component axes, AX1 and AX2. The first group (G1) was $\mathrm{K}^{+}$-responsive and positive for AX1 (Figure 1). G1 contains nine genotypes including ZUG403, YUQS, Keel, YSMI, YSM3, ZP2, Flagship, Dash and Gebeina (Figure 1). These genotypes showed the highest values for grain weight, grain number and number of spikes (Tables 4, 5 and S4). The second group (G2) was neutral for AX1 but positive for AX2 (Figure 6) and contained seven genotypes including Skiff, ZUG293, Gairdner, Yerong, Schooner, YF374 and CM72. RGZLL. The genotypes in this group were taller and 
had the greatest shoot dry weight and tiller number but had intermediate values for grain weight, number of grains and number of spikes. Thus, these were classified as moderately $\mathrm{K}^{+}$responsive. The third group (G3) was negative for AX1 (Figure 6) and contained 14 genotypes (YYXT, Dayton, DYSYH, Franklin, Yiwu Erleng, Yu6472, TF026, TX9425, Yan89110, Yan90260, Kinu Nijo 6, Naso Nijo, Numar and RGZLL). These genotypes had the lowest shoot dry weight, were shorter, and had fewer tillers, grains, grain weight and the number of spikes and were classified as less responsive to $\mathrm{K}^{+}$fertilization.

\section{Dendrogram}

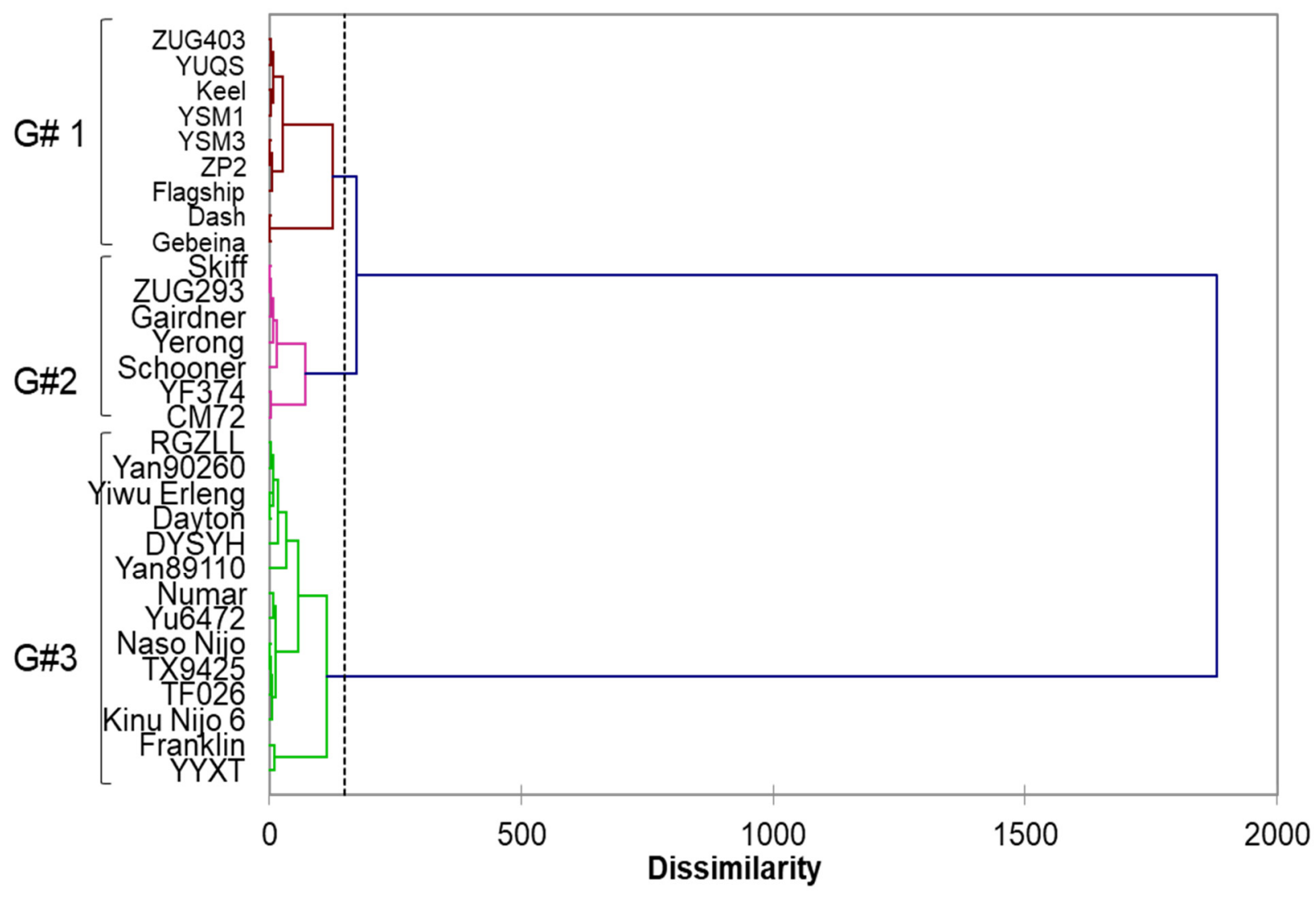

Figure 1. Dendogram based on all $\mathrm{K}$ treatments. The dendrogram shows fusion levels at which the groups join. The vertical dashed line represents the truncation into three genotype groups using Ward's agglomerative clustering algorithm. Group one contains nine genotypes (ZUG403, YUQS, Keel, YSMI, YSM3, ZP2, Flagship, Dash and Gebeina), group two contains seven genotypes (Skiff, ZUG293, Gairdner, Yerong, Schooner, YF374 and CM72), group three contains fourteen genotypes (YYXT, Dayton, DYSYH, Franklin, Yiwu Erleng, Yu6472, TF026, TX9425, Yan89110, Yan90260, Kinu Nijo 6, Naso Nijo, Numar and RGZLL).

\subsection{Correlation between Components of Yield}

The correlation between grain weight and shoot dry weight, grain numbers, tiller number, plant height and spike numbers were drawn to check the relevance of different variables (Table 2). The actual data (mean values) for tiller numbers, plant height and spike numbers are given in supplementary data (Tables S2-S4). Dry weight showed a positive correlation with grain weight only at $0.002 \mathrm{mM} \mathrm{K}^{+}$level (Table 2). A strong positive correlation was found between grain weight and grain numbers and spike numbers for all $\mathrm{K}^{+}$treatments. These results indicated that grain number and spike numbers are very important traits because it showed a strong correlation to grain yield (Table 2).Tiller numbers and plant height showed a very weak correlation with grain weight (Table 2). The results also indicate that more tillers did not produce more fertile spikes and consequently did not increase grain yield. 
Table 2. Correlation between grain weight $\mathrm{g}$ / plant and different variables (shoot dry weight, grain numbers, tiller numbers, plant height and spike numbers). The values in bold are significantly different at $<0.05$.

\begin{tabular}{|c|c|c|c|c|}
\hline \multirow{2}{*}{ Variables } & \multicolumn{4}{|c|}{ Grain Weight g/Plant } \\
\hline & $0.002 \mathrm{mM}$ & $0.02 \mathrm{mM}$ & $2 \mathrm{mM}$ & $20 \mathrm{mM}$ \\
\hline Dry Weight & 0.422 & 0.0029 & 0.007 & 0.0004 \\
\hline Grain No. & 0.838 & 0.852 & 0.852 & 0.684 \\
\hline Tiller No. & 0.001 & 0.002 & 0.003 & 0.002 \\
\hline Plant Height & 0.176 & 0.064 & 0.049 & 0.084 \\
\hline Spike No. & 0.628 & 0.642 & 0.378 & 0.342 \\
\hline
\end{tabular}

When the groups of genotypes G1, G2 and G3 were compared for each $\mathrm{K}^{+}$treatment, they showed a significant genotypic variation (Figure 2). Group 3 showed a significantly lower grain number and grain weight per plant. The other two groups showed a slightly low significant difference in grain number only but were not significantly different for shoot dry weight and grain weight (Figure 2).
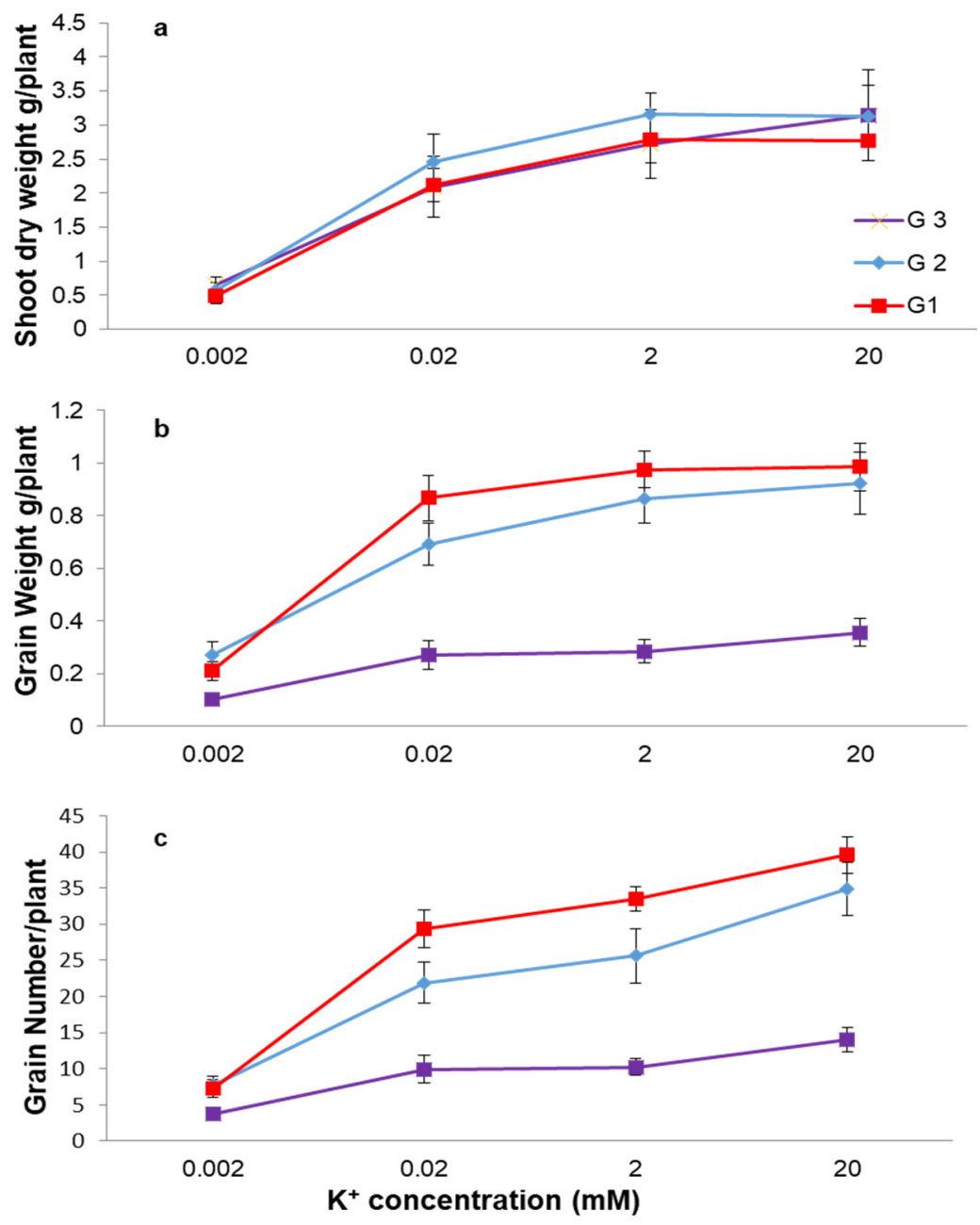

Figure 2. Comparison of the groups produced by cluster analysis, showing the differences in mean values between groups in (a) shoot dry weight (b) grain weight and (c) grain number at different $\mathrm{K}^{+}$ treatments. 


\subsection{Shoot Dry Weight}

The different levels of $\mathrm{K}$ availability showed a significant effect on plant shoot dry weight (Table 3). When plants were grown at the lowest $(0.002 \mathrm{mM}) \mathrm{K}$ level, shoot dry weight ranged from highest 1.66-0.21 g/plant, with cultivar Franklin having the highest and Yu6472-the lowest DW (Table 3). At the highest level $(20 \mathrm{mM})$ of $\mathrm{K}$ most of the genotypes showed a 3-5 folds higher shoot dry weight compared with the lowest $\mathrm{K}^{+}$level (Table 3). An increase in $\mathrm{K}$ supply led to an increase in shoot dry weight accumulation in all genotypes, although the extent of their response differed significantly between genotypes. Franklin, DYSYH and YYXT showed the greatest shoot dry weight values for all $\mathrm{K}$ treatments (Table 3).

Table 3. Genotypic variation in the shoot dry weight $\mathrm{g} / \mathrm{plant}$ of barley genotypes under different concentration of $\mathrm{K}^{+}$supply. Values are mean $\pm \mathrm{SE}(n=6)$ and $\mathrm{G}$ represents different groups of genotypes. Genotypes have been divided into three group G1, G2 and G3 according to cluster analysis (see Section 3.1 and Figure 1).

\begin{tabular}{|c|c|c|c|c|c|}
\hline & \multirow[b]{2}{*}{ Genotype } & \multicolumn{4}{|c|}{$\mathrm{K}^{+}$Concentration $(\mathrm{mM})$} \\
\hline & & 0.002 & 0.02 & 2 & 20 \\
\hline \multirow{9}{*}{ G1 } & $\mathrm{ZuG} 403$ & $0.28 \pm 0.01$ & $2.18 \pm 0.15$ & $2.63 \pm 0.04$ & $2.43 \pm 0.08$ \\
\hline & YUQS & $0.25 \pm 0.02$ & $2.67 \pm 0.03$ & $4.99 \pm 0.36$ & $4.43 \pm 0.16$ \\
\hline & Keel & $0.23 \pm 0.02$ & $0.89 \pm 0.09$ & $1.49 \pm 0.16$ & $1.54 \pm 0.03$ \\
\hline & YSM1 & $0.49 \pm 0.08$ & $1.58 \pm 0.10$ & $2.11 \pm 0.03$ & $1.85 \pm 0.10$ \\
\hline & YSM3 & $0.33 \pm 0.03$ & $1.76 \pm 0.13$ & $2.28 \pm 0.27$ & $2.21 \pm 0.24$ \\
\hline & $\mathrm{ZP2}$ & $0.28 \pm 0.03$ & $2.94 \pm 0.23$ & $2.65 \pm 0.35$ & $2.54 \pm 0.63$ \\
\hline & Flagship & $0.49 \pm 0.03$ & $1.67 \pm 0.13$ & $2.27 \pm 0.60$ & $2.99 \pm 0.13$ \\
\hline & Dash & $0.78 \pm 0.17$ & $2.18 \pm 0.01$ & $2.76 \pm 0.28$ & $3.54 \pm 0.19$ \\
\hline & Gebeina & $1.28 \pm 0.02$ & $3.16 \pm 0.40$ & $3.93 \pm 0.25$ & $3.43 \pm 0.09$ \\
\hline \multirow{7}{*}{ G2 } & Skiff & $0.37 \pm 0.03$ & $1.44 \pm 0.08$ & $2.51 \pm 0.26$ & $2.24 \pm 0.19$ \\
\hline & ZUG293 & $0.85 \pm 0.05$ & $3.98 \pm 0.01$ & $3.68 \pm 0.16$ & $4.17 \pm 0.01$ \\
\hline & Gairdner & $1.13 \pm 0.04$ & $3.81 \pm 0.09$ & $4.15 \pm 0.45$ & $5.24 \pm 0.13$ \\
\hline & Yerong & $0.26 \pm 0.06$ & $2.01 \pm 0.18$ & $3.09 \pm 0.29$ & $2.23 \pm 0.27$ \\
\hline & Schooner & $0.39 \pm 0.04$ & $1.84 \pm 0.11$ & $2.89 \pm 0.18$ & $3.04 \pm 0.44$ \\
\hline & YF374 & $0.41 \pm 0.01$ & $1.38 \pm 0.28$ & $1.85 \pm 0.08$ & $1.93 \pm 0.04$ \\
\hline & CM72 & $0.58 \pm 0.09$ & $2.73 \pm 0.49$ & $3.93 \pm 0.07$ & $3.03 \pm 0.03$ \\
\hline \multirow{14}{*}{ G3 } & RGZLL & $1.17 \pm 0.35$ & $0.98 \pm 0.13$ & $1.59 \pm 0.43$ & $2.2 \pm 0.18$ \\
\hline & Yan90260 & $0.31 \pm 0.03$ & $0.77 \pm 0.01$ & $0.94 \pm 0.18$ & $0.92 \pm 0.20$ \\
\hline & Yiwu Erleng & $0.78 \pm 0.21$ & $2.87 \pm 0.50$ & $4.62 \pm 0.50$ & $4.72 \pm 0.13$ \\
\hline & Dayton & $0.93 \pm 0.17$ & $3.68 \pm 0.52$ & $4.73 \pm 0.53$ & $5.25 \pm 0.01$ \\
\hline & DYSYH & $1.25 \pm 0.50$ & $4.94 \pm 0.24$ & $5.92 \pm 0.78$ & $8.02 \pm 0.38$ \\
\hline & Yan89110 & $0.32 \pm 0.01$ & $1.36 \pm 0.08$ & $2.08 \pm 0.13$ & $2.28 \pm 0.04$ \\
\hline & Numar & $0.38 \pm 0.03$ & $1.08 \pm 0.03$ & $1.53 \pm 0.06$ & $2.16 \pm 0.03$ \\
\hline & Yu 6472 & $0.21 \pm 0.01$ & $1.18 \pm 0.2$ & $1.55 \pm 0.20$ & $1.38 \pm 0.01$ \\
\hline & Naso Nijo & $0.25 \pm 0.02$ & $0.53 \pm 0.12$ & $0.68 \pm 0.16$ & $0.61 \pm 0.01$ \\
\hline & TX9425 & $0.26 \pm 0.01$ & $1.25 \pm 0.02$ & $1.88 \pm 0.09$ & $1.72 \pm 0.08$ \\
\hline & TF026 & $0.24 \pm 0.06$ & $0.93 \pm 0.05$ & $1.78 \pm 0.03$ & $1.54 \pm 0.13$ \\
\hline & Kinu Nijo 6 & $0.24 \pm 0.01$ & $0.52 \pm 0.05$ & $0.69 \pm 0.20$ & $0.69 \pm 0.10$ \\
\hline & Franklin & $1.66 \pm 0.06$ & $4.46 \pm 0.46$ & $4.99 \pm 0.08$ & $7.56 \pm 0.99$ \\
\hline & YYXT & $1.03 \pm 0.02$ & $4.8 \pm 0.17$ & $5.18 \pm 0.30$ & $5.05 \pm 0.01$ \\
\hline
\end{tabular}

$\mathrm{LSD}_{0.002}=0.15, \mathrm{LSD}_{0.02}=0.41, \mathrm{LSD}_{2}=0.67, \mathrm{LSD}_{20}=0.44$.

The relative shoot dry weights (calculated as \% between appropriate treatment and that for $2 \mathrm{mM}$, considered as optimal) is shown in Figure 3. The highest $(20 \mathrm{mM})$ treatment has benefited only $1 / 3$ of all genotypes, and there was about 10 -fold difference in performance of some genotypes grown at lowest $(0.002 \mathrm{mM}) \mathrm{K}$ levels (e.g., $8 \%$ in Yerong vs. $75 \%$ in RGZLL; Figure 3). 


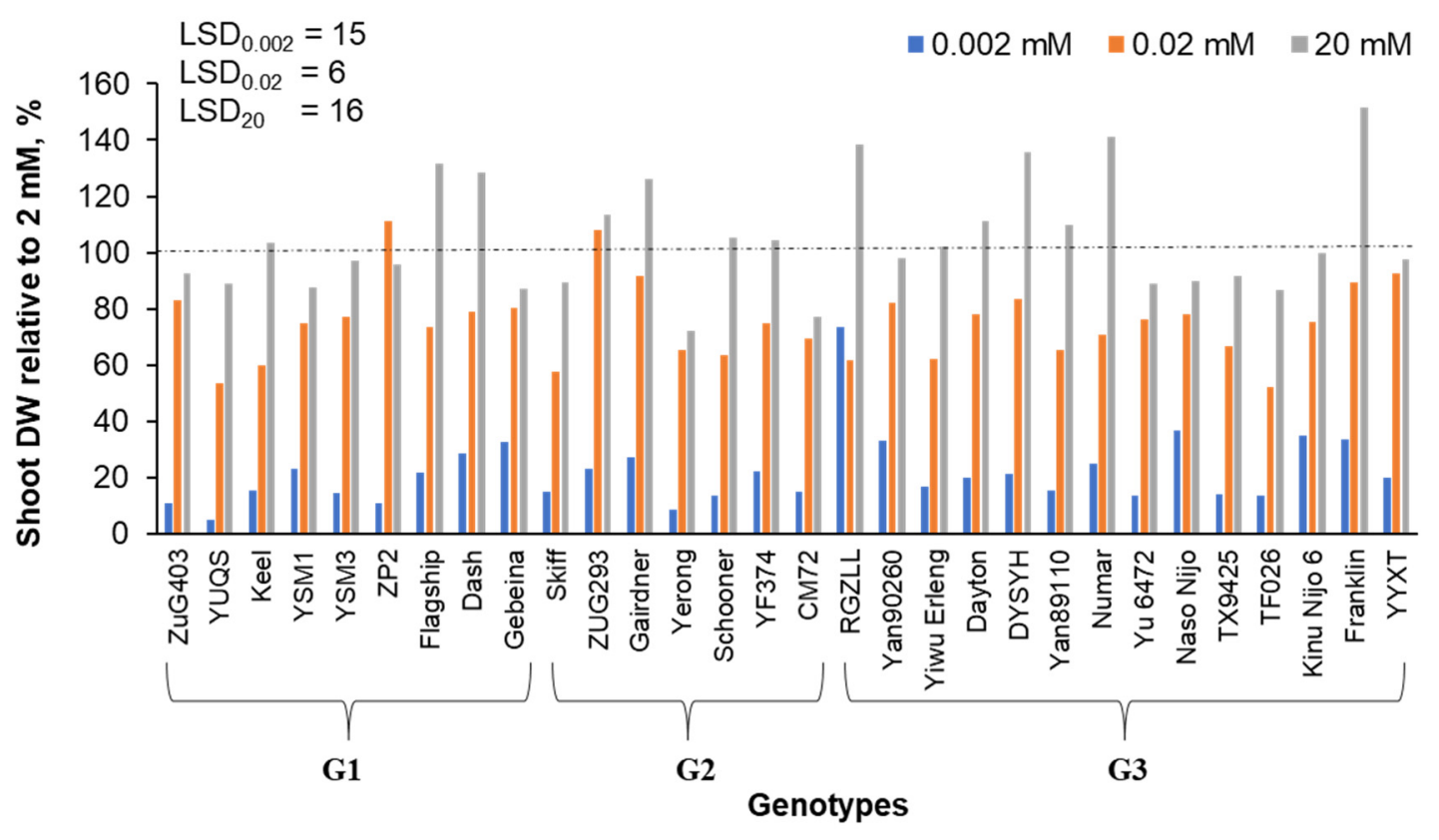

Figure 3. Relative shoot dry weight of 30 barley genotypes grown at different $\mathrm{K}$ levels $(0.002 \mathrm{mM}, 0.02 \mathrm{mM}$ and $20 \mathrm{mM})$ as compared to optimal $2 \mathrm{mM}$ treatment. Genotypes were divided into three groups G1, G2 and G3 (see Figure 1 for details) produced by cluster analysis. Data are means \pm SE $(n=6)$. LSD are based on significance at $p<0.05$ level.

\subsection{Genotypic Variability in Grain Weight}

Plant grain weight also showed a significant variation in genotypes at a different level of $\mathrm{K}^{+}$availability (Table 4). Most genotypes showed the highest grain weight difference between the lowest $(0.002 \mathrm{mM}) \mathrm{K}^{+}$level and $0.02 \mathrm{mM}$, and a further increase in $\mathrm{K}^{+}$concentration did not make a significant difference in grain weight in most genotypes. For most genotypes, the $0.02 \mathrm{mM} \mathrm{K}^{+}$treatment showed the highest grain weight (Table 4) but some genotypes like Kinu Nijo 6 and Naso Nijo did not respond to increased $\mathrm{K}^{+}$availability in the soil. These results indicate that an increase in $\mathrm{K}^{+}$availability did not gradually increase grain weight in barley and that $0.02 \mathrm{mM} \mathrm{K}^{+}$would be the threshold of deficiency for grain weight for most genotypes. The highest variability between genotypes was noticed in the $0.002 \mathrm{mM}$ potassium treatment, where genotypes Dayton, DYSYH and RGZLL did not produce any grain (Table 4$)$.

Table 4. Genotypic variation in the grain weight $\mathrm{g} / \mathrm{plant}$ of barley genotypes under different concentration of $\mathrm{K}^{+}$supply. Values are mean $\pm \mathrm{SE}(n=6)$ and $\mathrm{G}$ represents different groups of genotypes. Genotypes have been divided into three group G1, G2 and G3 according to cluster analysis (see Section 3.1 and Figure 1).

\begin{tabular}{llllll}
\hline & & \multicolumn{4}{c}{$\mathbf{K}^{+}$Concentration $(\mathbf{m M})$} \\
\hline & Genotype & $\mathbf{0 . 0 0 2}$ & $\mathbf{0 . 0 2}$ & $\mathbf{2}$ & $\mathbf{2 0}$ \\
\hline ZuG403 & $0.2 \pm 0.01$ & $1.05 \pm 0.03$ & $1.2 \pm 0.20$ & $1.03 \pm 0.05$ \\
YUQS & $0.2 \pm 0.01$ & $1.05 \pm 0.03$ & $1.2 \pm 0.20$ & $1.03 \pm 0.05$ \\
& Keel & $0.25 \pm 0.02$ & $0.38 \pm 0.08$ & $0.93 \pm 0.19$ & $0.78 \pm 0.06$ \\
& YSM1 & $0.06 \pm 0.02$ & $0.62 \pm 0.10$ & $0.67 \pm 0.07$ & $0.92 \pm 0.01$ \\
& YSM3 & $0.26 \pm 0.06$ & $0.94 \pm 0.15$ & $1.22 \pm 0.11$ & $0.65 \pm 0.11$ \\
& ZP2 & $0.28 \pm 0.03$ & $1.21 \pm 0.05$ & $1.09 \pm 0.06$ & $1.18 \pm 0.03$ \\
& Flagship & $0.38 \pm 0.09$ & $0.69 \pm 0.04$ & $0.75 \pm 0.10$ & $0.97 \pm 0.29$ \\
& Dash & $0.16 \pm 0.05$ & $0.91 \pm 0.10$ & $0.92 \pm 0.16$ & $0.67 \pm 0.03$ \\
& Gebeina & $0.06 \pm 0.01$ & $1.13 \pm 0.04$ & $1.2 \pm 0.13$ & $1.48 \pm 0.11$ \\
\hline
\end{tabular}


Table 4. Cont.

\begin{tabular}{|c|c|c|c|c|c|}
\hline & \multirow[b]{2}{*}{ Genotype } & \multicolumn{4}{|c|}{$\mathrm{K}^{+}$Concentration $(\mathrm{mM})$} \\
\hline & & 0.002 & 0.02 & 2 & 20 \\
\hline \multirow{7}{*}{ G2 } & Skiff & $0.4 \pm 0.05$ & $0.43 \pm 0.05$ & $1.15 \pm 0.08$ & $0.88 \pm 0.06$ \\
\hline & ZUG293 & $0.14 \pm 0.01$ & $0.92 \pm 0.00$ & $0.98 \pm 0.05$ & $1.08 \pm 0.00$ \\
\hline & Gairdner & $0.03 \pm 0.01$ & $0.52 \pm 0.06$ & $0.48 \pm 0.26$ & $0.61 \pm 0.28$ \\
\hline & Yerong & $0.34 \pm 0.01$ & $0.9 \pm 0.14$ & $0.93 \pm 0.07$ & $1.15 \pm 0.05$ \\
\hline & Schooner & $0.32 \pm 0.03$ & $0.93 \pm 0.16$ & $1.02 \pm 0.57$ & $0.76 \pm 0.03$ \\
\hline & YF374 & $0.4 \pm 0.04$ & $0.55 \pm 0.26$ & $0.93 \pm 0.07$ & $0.55 \pm 0.02$ \\
\hline & CM72 & $0.28 \pm 0.07$ & $0.59 \pm 0.07$ & $0.56 \pm 0.11$ & $1.43 \pm 0.04$ \\
\hline \multirow{14}{*}{ G3 } & RGZLL & $0.1 \pm 0.01$ & $0.14 \pm 0.01$ & $0.22 \pm 0.12$ & $0.33 \pm 0.15$ \\
\hline & Yan90260 & $0.15 \pm 0.00$ & $0.27 \pm 0.05$ & $0.43 \pm 0.11$ & $0.34 \pm 0.04$ \\
\hline & Yiwu Erleng & $0.04 \pm 0.04$ & $0.54 \pm 0.01$ & $0.16 \pm 0.15$ & $0.24 \pm 0.07$ \\
\hline & Dayton & $0.1 \pm 0.01$ & $0.1 \pm 0.01$ & $0.35 \pm 0.03$ & $0.41 \pm 0.01$ \\
\hline & DYSYH & $0.1 \pm 0.01$ & $0.07 \pm 0.01$ & $0.16 \pm 0.11$ & $0.75 \pm 0.04$ \\
\hline & Yan89110 & $0.12 \pm 0.03$ & $0.49 \pm 0.05$ & $0.47 \pm 0.08$ & $0.31 \pm 0.16$ \\
\hline & Numar & $0.2 \pm 0.01$ & $0.45 \pm 0.01$ & $0.39 \pm 0.30$ & $0.74 \pm 0.16$ \\
\hline & Yu 6472 & $0.18 \pm 0.01$ & $0.61 \pm 0.10$ & $0.61 \pm 0.25$ & $0.43 \pm 0.11$ \\
\hline & Naso Nijo & $0.21 \pm 0.02$ & $0.28 \pm 0.05$ & $0.4 \pm 0.14$ & $0.26 \pm 0.01$ \\
\hline & TX9425 & $0.06 \pm 0.03$ & $0.33 \pm 0.05$ & $0.2 \pm 0.06$ & $0.41 \pm 0.05$ \\
\hline & TF026 & $0.18 \pm 0.03$ & $0.32 \pm 0.01$ & $0.17 \pm 0.16$ & $0.19 \pm 0.12$ \\
\hline & Kinu Nijo 6 & $0.2 \pm 0.02$ & $0.27 \pm 0.03$ & $0.29 \pm 0.10$ & $0.16 \pm 0.01$ \\
\hline & Franklin & $0.03 \pm 0.03$ & $0.04 \pm 0.01$ & $0.1 \pm 0.01$ & $0.06 \pm 0.01$ \\
\hline & YYXT & $0.03 \pm 0.02$ & $0.1 \pm 0.01$ & $0.14 \pm 0.01$ & $0.38 \pm 0.02$ \\
\hline
\end{tabular}

$\overline{\mathrm{LSD}}_{0.002}=0.09, \mathrm{LSD}_{0.02}=0.16, \mathrm{LSD}_{2}=0.43, \mathrm{LSD}_{20}=0.21$.

Similarly, relative grain weights were for $0.002 \mathrm{mM}, 0.02 \mathrm{mM}, 20 \mathrm{mM}$ treatments compared with optimal $2 \mathrm{mM}$ (Figure 4). The grain weights at $0.02 \mathrm{mM}$ did not show a significant difference when compared with a higher level of $20 \mathrm{mM}$ but $0.02 \mathrm{mM}$ and $20 \mathrm{mM}$ both showed a significant difference as compared to the lower level at $0.002 \mathrm{~K}^{+}$ (Figure 4).

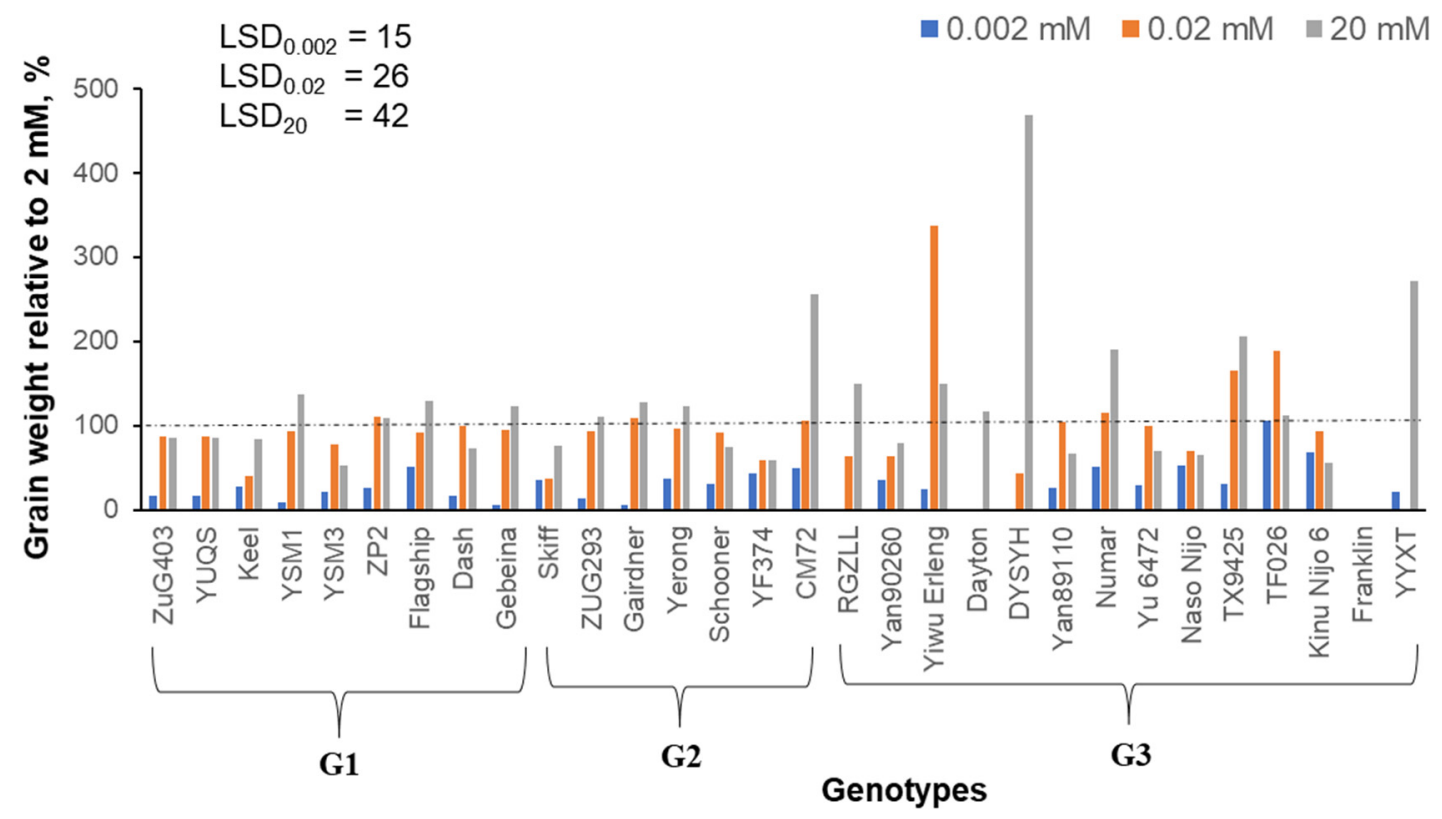

Figure 4. Relative grain weight of 30 barley genotypes grown at different $\mathrm{K}$ levels $(0.002 \mathrm{mM}, 0.02 \mathrm{mM}$ and $20 \mathrm{mM})$ as compared to optimal $2 \mathrm{mM}$ treatment. Genotypes were divided into three groups G1, G2 and G3 (see Figure 1 for details) produced by cluster analysis. Data are means \pm SE $(n=6)$. LSD are based on significance at $p<0.05$ level. 


\subsection{Grain Number}

Grain numbers showed a similar trend as grain weight in response to increased $\mathrm{K}^{+}$ availability in the soil (Table 5). Most of the genotypes in every group showed the highest grain number difference between the lowest $0.002 \mathrm{mM}$ and $0.02 \mathrm{mM} \mathrm{K}^{+}$, and a further increase in $\mathrm{K}^{+}$availability did not result in a significant beneficial effect on grain number in most genotypes. At $0.02 \mathrm{mM} \mathrm{K}^{+}$treatment, most of the genotypes showed the highest positive effect on grain numbers (Table 5). Genotype Gebeina showed a 21-fold change at $0.002 \mathrm{mM}$ when compared with $0.02 \mathrm{mM} \mathrm{K}^{+}$. However, some genotypes (e.g., Franklin, TF026, Kinu Nijo) did not show a significant change across different $K^{+}$levels (Table 5).

Table 5. Genotypic variation in the grain numbers of barley genotypes under different concentration of $\mathrm{K}^{+}$supply. Values are mean $\pm \mathrm{SE}(n=6)$ and $\mathrm{G}$ represents different groups of genotypes. Genotypes have been divided into three group G1, G2 and G3 according to cluster analysis (see Section 3.1 and Figure 1).

\begin{tabular}{|c|c|c|c|c|c|}
\hline & \multirow[b]{2}{*}{ Genotype } & \multicolumn{4}{|c|}{$\mathrm{K}^{+}$Concentration (mM) } \\
\hline & & 0.002 & 0.02 & 2 & 20 \\
\hline \multirow{9}{*}{ G1 } & $\mathrm{ZuG} 403$ & $6.2 \pm 0.1$ & $23.2 \pm 3$ & $30 \pm 1.7$ & $38.5 \pm 8$ \\
\hline & YUQS & $6.6 \pm 0.2$ & $26.6 \pm 2.4$ & $34.1 \pm 3.1$ & $36.7 \pm 0.1$ \\
\hline & Keel & $9.6 \pm 03$ & $15.4 \pm 3.3$ & $27.9 \pm 0.6$ & $38.6 \pm 4.6$ \\
\hline & YSM1 & $1.8 \pm 0.6$ & $28.4 \pm 4.8$ & $25.8 \pm 3.3$ & $43.4 \pm 3.6$ \\
\hline & YSM3 & $9.2 \pm 0.8$ & $29.9 \pm 2.9$ & $37.2 \pm 5.6$ & $32.8 \pm 5.5$ \\
\hline & $\mathrm{ZP} 2$ & $9.8 \pm 1.7$ & $34.3 \pm 0.8$ & $35.5 \pm 3$ & $27.3 \pm 1.4$ \\
\hline & Flagship & $12.1 \pm 2.3$ & $26.3 \pm 0.2$ & $32.1 \pm 3.8$ & $41.4 \pm 2.4$ \\
\hline & Dash & $9.2 \pm 3$ & $39.6 \pm 0.3$ & $42.5 \pm 5.8$ & $41.6 \pm 2.4$ \\
\hline & Gebeina & $1.9 \pm 0.5$ & $40.1 \pm 1.3$ & $36.3 \pm 4.9$ & $55.6 \pm 4.4$ \\
\hline \multirow{7}{*}{ G2 } & Skiff & $11.5 \pm 2.7$ & $15 \pm 1.7$ & $41.2 \pm 10.8$ & $27.8 \pm 0.8$ \\
\hline & ZUG293 & $7.2 \pm 1.8$ & $29.3 \pm 0.1$ & $28.1 \pm 1.1$ & $32.3 \pm 0.1$ \\
\hline & Gairdner & $1.7 \pm 0.8$ & $21.8 \pm 1.6$ & $18.2 \pm 9.7$ & $49.2 \pm 3.8$ \\
\hline & Yerong & $7.1 \pm 0.4$ & $29.5 \pm 2.8$ & $24.2 \pm 0.3$ & $37.3 \pm 5.3$ \\
\hline & Schooner & $9.3 \pm 0.8$ & $29.4 \pm 3.4$ & $34.2 \pm 2$ & $36.8 \pm 0.3$ \\
\hline & YF374 & $10.4 \pm 0.6$ & $16.1 \pm 8.6$ & $21.8 \pm 2.3$ & $19.3 \pm 0.3$ \\
\hline & CM72 & $7 \pm 0.8$ & $12.2 \pm 0.3$ & $11.7 \pm 2.5$ & $41.5 \pm 0.2$ \\
\hline \multirow{14}{*}{ G3 } & RGZLL & $0.1 \pm 0.1$ & $4.3 \pm 2.2$ & $8.7 \pm 2$ & $20.7 \pm 7.7$ \\
\hline & Yan90260 & $4.8 \pm 0.1$ & $9.2 \pm 1.3$ & $11.4 \pm 3.6$ & $14.7 \pm 3.2$ \\
\hline & Yiwu Erleng & $1.2 \pm 1.2$ & $20.6 \pm 1.1$ & $7.3 \pm 6.9$ & $7.8 \pm 1.3$ \\
\hline & Dayton & $0.1 \pm 0.1$ & $0.1 \pm 0.1$ & $18.1 \pm 4.1$ & $16.6 \pm 1.9$ \\
\hline & DYSYH & $0.1 \pm 0.1$ & $6.1 \pm 0.3$ & $12.3 \pm 0.6$ & $30 \pm 0.1$ \\
\hline & Yan89110 & $5.5 \pm 0.7$ & $11.8 \pm 1.8$ & $11.8 \pm 0.9$ & $12.06 \pm 6.8$ \\
\hline & Numar & $5.8 \pm 0.5$ & $12.6 \pm 0.9$ & $14.2 \pm 4.2$ & $17.1 \pm 0.9$ \\
\hline & Yu 6472 & $5.5 \pm 0.5$ & $21.7 \pm 1.7$ & $15 \pm 5$ & $13.8 \pm 3.8$ \\
\hline & Naso Nijo & $7.7 \pm 0.5$ & $9.3 \pm 1.1$ & $12.8 \pm 3$ & $12.9 \pm 1.6$ \\
\hline & TX9425 & $2.4 \pm 0.8$ & $16.4 \pm 4.6$ & $8.8 \pm 4.7$ & $17.1 \pm 3.4$ \\
\hline & TF026 & $9.83 \pm 0.5$ & $15 \pm 1.7$ & $7.58 \pm 7.3$ & $9.83 \pm 6.5$ \\
\hline & Kinu Nijo 6 & $6.7 \pm 0.5$ & $10.09 \pm 0.8$ & $9.3 \pm 2.1$ & $8.2 \pm 0.7$ \\
\hline & Franklin & $0.9 \pm 0.9$ & $1.4 \pm 0.4$ & $0.1 \pm 0.1$ & $2.7 \pm 0.2$ \\
\hline & YYXT & $1.5 \pm 0.8$ & $0.1 \pm 0.1$ & $6.5 \pm 1.5$ & $12.5 \pm 0.1$ \\
\hline
\end{tabular}

When relative grain numbers were calculated for three $\mathrm{K}^{+}$levels $(0.002 \mathrm{mM}, 0.02 \mathrm{mM}$, $20 \mathrm{mM}$ ) relative to $2 \mathrm{mM}$ (Figure 5), the grain numbers showed a similar result to grain weight (Figure 4). The grain numbers percentage at $0.02 \mathrm{mM}$ did not show a significant difference when compared with a higher level of $20 \mathrm{mM}$ but $0.02 \mathrm{mM}$ and $20 \mathrm{mM}$ both showed a significant difference as compared to the lower level at $0.002 \mathrm{~K}^{+}$(Figure 5). 


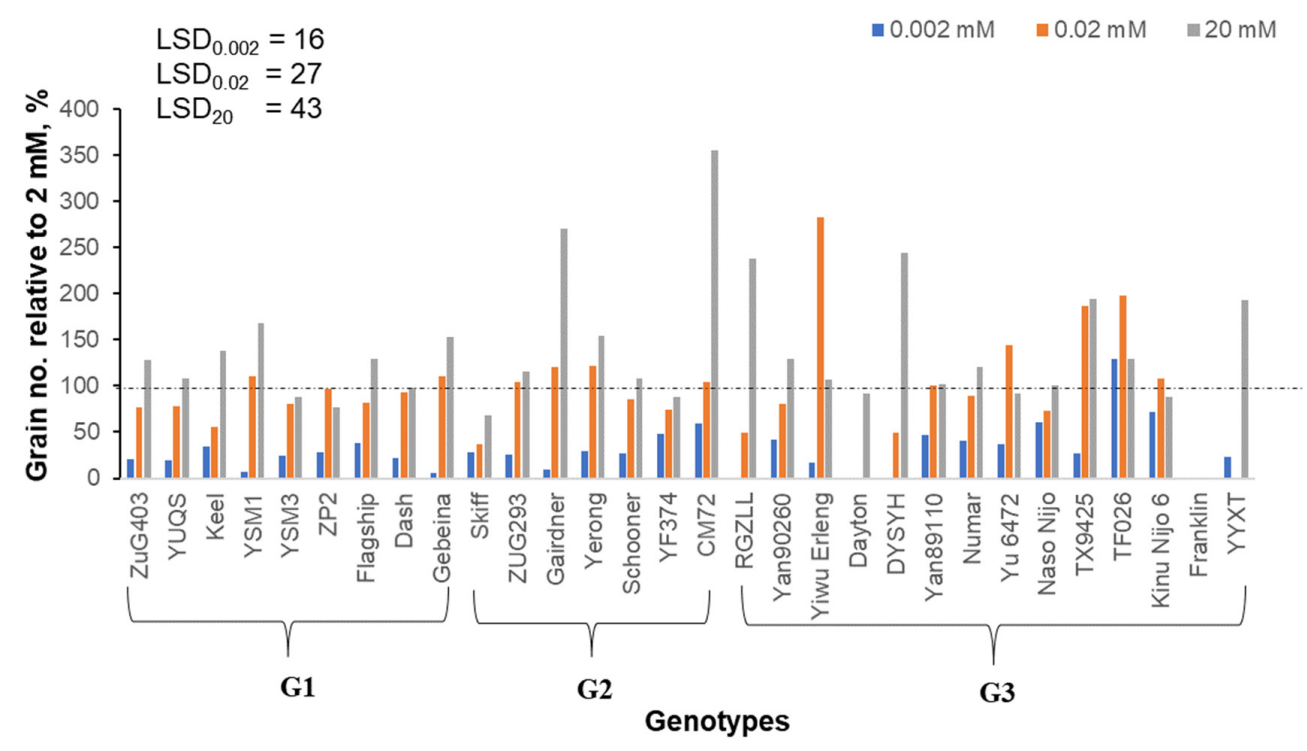

Figure 5. Relative grain number of 30 barley genotypes grown at different $\mathrm{K}$ levels $(0.002 \mathrm{mM}, 0.02 \mathrm{mM}$ and $20 \mathrm{mM})$ as compared to optimal $2 \mathrm{mM}$ treatment. Genotypes were divided into three groups G1, G2 and G3 (see Figure 1 for details) produced by cluster analysis. Data are means \pm SE $(n=6)$. LSD are based on significance at $p<0.05$ level.

\subsection{Principle Component Analysis}

Hierarchical cluster analysis (HCA) was used to categorize genotypes at the first stage and principal component analysis (PCA) based on the means of all variables was used for further analysis. The ordination analysis indicated that principal component axes F1 and F2 accounted for 42 and 32\% of the sums of squares, respectively (Figure 6). F1 was mainly linked to spike number, while F2 was influenced by tiller number and dry shoot weight.

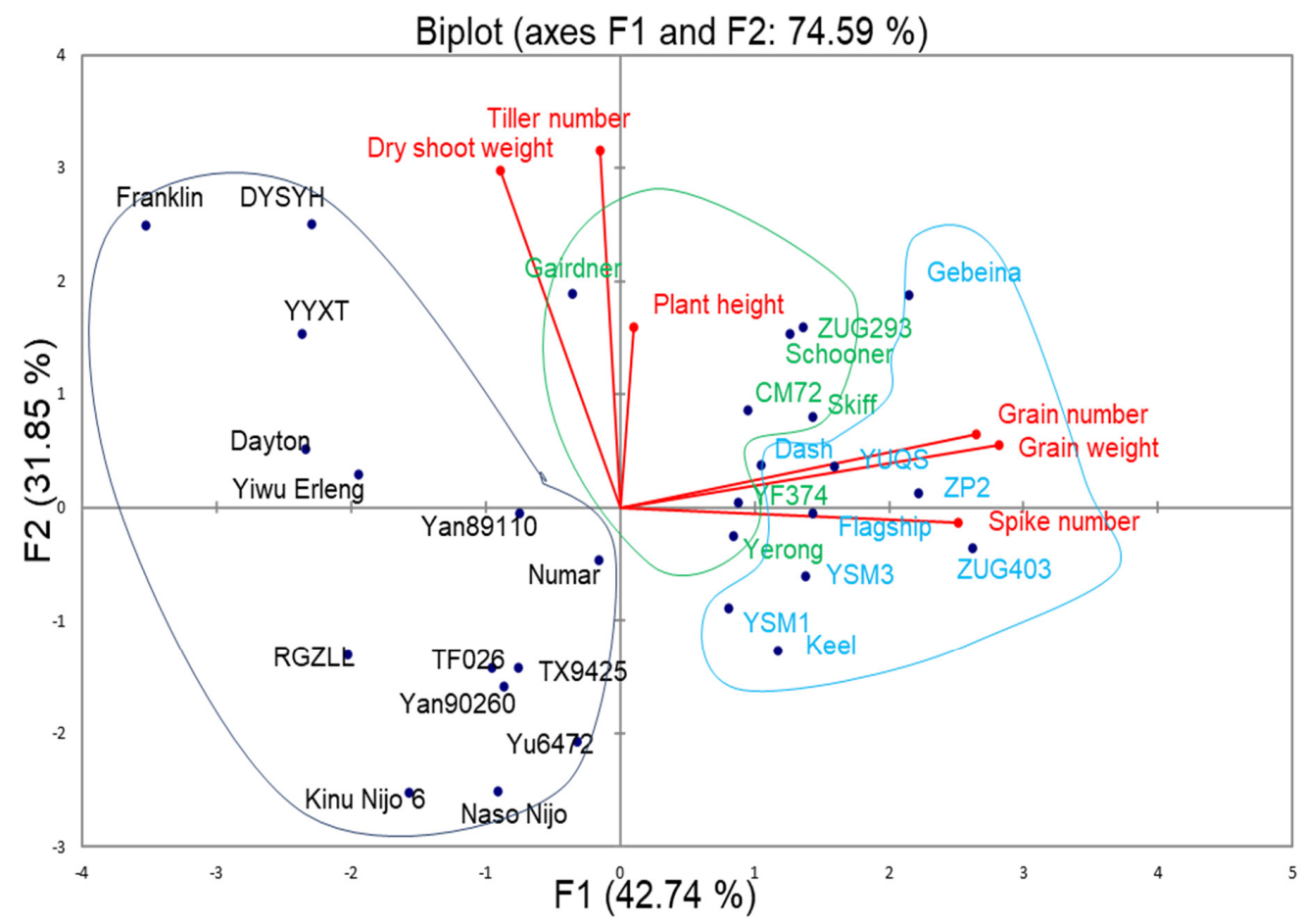

Figure 6. Principle component analysis for AX1 and AX2 for all data. The axes accounted for $74.8 \%$ of the sums of squares. Genotype groups correspond to the following colours: G\#1, blue; G\#2, green; and G\#3, purple. Principal component analysis (PCA) was performed using traits mean values with Kaiser's criterion (i.e., eigenvalue more than 1) using XLSTAT software. 


\section{Discussion}

Potassium (K) is an essential mineral nutrient for plant growth and development. $\mathrm{K}$ is one of the most abundant elements in plants and plays an important role in enzyme activation, metabolism, cell development, cytosolic $\mathrm{pH}$ regulation [4,31]. However, plants are often subjected to nutritional stress due to low $\mathrm{K}$ supply in soils around the globe. Therefore, it is vital to identify the genotypes both responsive to $\mathrm{K}$ fertilization and also able to maximise KUE. It is also critical to understand the agronomical traits that contributed to high yield under conditions of $\mathrm{K}$ deficiency and develop some proxies for efficient germplasm screening. Barley is more tolerant to poor nutritional supply as compared to other cereal crops. K deficiency to plants also occurs due to high yield pressure and frequent crop intensity $[32,33]$. Crops including wheat, rice, maize and barley showed a big variation in the response to K deficiency among species and genotypes within species [14,34,35], indicating strong genetic control of KUE and nutrition. One of the major limitations for developing K nutrient efficient crops is the limited understanding of the directly related traits involved in genotypic diversity.

HCA was used to differentiate between genotype responses at different levels of $\mathrm{K}$ supply. As a result, the genotypes were divided into three groups G1, G2 and G3 (see Section 3). According to PCA, the genotypes in the G1 group were highly responsive to $\mathrm{K}$ and showed the highest values for grain weight, grain number and number of spikes. The second group (G2) showed a neutral response and in this group, plants were taller and had the greatest shoot dry weight and tiller number but had intermediate values for grain weight, number of grains and number of spikes. Thus, these were classified as moderately $\mathrm{K}^{+}$responsive. The last group (G3) was negative for AX1 and contained 14 genotypes. The genotypes in this group showed the lowest shoot dry weight, were shorter, and had fewer tillers, grains, grain weight and the number of spikes and were classified as unresponsive to $\mathrm{K}^{+}$fertilization. This variable response to low $\mathrm{K}^{+}$exhibited by these genotypes could be a consequence of the difference in their ability of $\mathrm{K}^{+}$absorption and translocation by $\mathrm{K}^{+}$transporters and channels in the high and low-affinity uptake systems. In a similar study, Zeng et al. (2014) used a transcriptase profile of wild barley and reported XZ141 as less tolerant and XZ153 as an effective genotype to tolerate low $\mathrm{K}^{+}$nutrition stress to produce more dry weight [36]. So, this rapid tolerance to low $\mathrm{K}^{+}$nutrition in Franklin, Gebeina, RG2LL, Gairdner and DYSYH genotypes can be attributed to more uptake and accumulation of $\mathrm{K}^{+}$by barley plants. Consequently, our genotypes in relation to shoot dry weight can be ranked according to the following order: Schooner $>$ Numar $>$ Skiff $>$ YSM 3 > Yan $89110>$ Yan $0260>$ TX 9425 > YF 374 > Flagship > YSM 1 > Dasel > ZUG 293 > Dayton (Table 3).

Interestingly, the shoot dry weight showed a weak (negligible) correlation with grain weight at higher levels of $\mathrm{K}$ and only showed a significant correlation at the lowest level $(0.002 \mathrm{mM})$ of $\mathrm{K}$ (Table 2), indicating that shoot dry weight alone could not be used as a suitable selection criterion to investigate genotypic differences under $\mathrm{K}$ deficient conditions. In previous studies, shoot dry weight was reported as a weak indicator of low K efficiency at physiological maturity $[27,37]$. Higher levels of K significantly increased the plant height and tiller numbers but showed a very weak correlation with grain weight which indicates that the vegetative stage of the crop may not be related to K efficiency regarding grain number (Table 5). At the same time, grain numbers and spike numbers showed a very strong correlation with grain weight at all levels of $\mathrm{K}$ prompting a suggestion of their possible use as a proxy for KUE in future breeding programs.

In this study, the genotypes showed a great variation in data at different levels of $\mathrm{K}$. Increase in $\mathrm{K}^{+}$supply led to an increase in shoot dry weight accumulation in all genotypes with a huge variation in the response of different genotypes (Table 3). About $50 \%$ of genotypes showed highest grain yield at $20 \mathrm{mM}$ treatment, while another high peaked at $2 \mathrm{mM}$ treatment (Figure 3). Even in the former case, the difference in grain yield between 2- and 20-mM treatments was rather small, questioning the economic rationale of oversupplying $\mathrm{K}$. At the same time, most of the genotypes did not show a significant increase in the grain 
weight and grain numbers at the higher levels of $\mathrm{K}$ (Tables 4 and 5), indicating that the $0.02 \mathrm{mM} \mathrm{K}^{+}$would be the threshold of deficiency for grain weight and grain numbers for most genotypes. Thus, the effect of $\mathrm{K}$ on shoot growth and grain filling seems to be physiologically uncoupled. An increase in grain yield was linked to supplementation of the available supply of $\mathrm{K}$ in the soil [6,38]. A significant increase in the yield components was reported with the application of $\mathrm{K}$ fertilizer under low moisture conditions [39]. The increase in yield components with applied $\mathrm{K}^{+}$level might be due to efficient intake of $\mathrm{K}^{+}$ under deficient conditions, where many genotypes showed their capacity to assign biomass production to grain yield. The differences in metabolic pathways result in differences in energy distribution and capacity of low $\mathrm{K}^{+}$stress adaptation.

The results of the present study revealed the significant extent of genetic variation in barley adaptation to low $\mathrm{K}^{+}$availability. The most productive genotypes at low $\mathrm{K}^{+}$supply were Gebeina, Skiff, YF374 and Flagship and YF374. The less effective genotypes were Dayton, DYSYH, and RGZLL. The genotypes which were more effective at lower K supply and traits grain number and spike number which showed a strong correlation with grain yield are therefore recommended for mapping DH population, to reveal QTL responsible for potassium use efficiency in barley and incorporation into barely breeding programs.

Supplementary Materials: The following are available online at https://www.mdpi.com/article/10 .3390 /agronomy11112269/s1, Table S1: Thirty genotypes of barley and their origin, maturity type and row type and sensitivity to waterlogging. S-spring; W-winter. Table S2: Genotypic variability in height $\mathrm{cm}$ / plant of plants grown under various $\mathrm{K}^{+}$supply. Data are mean $\pm \mathrm{SE}(n=6)$. Genotypes have been divided into three group according to cluster analysis (see Section 3.1 and Figure 1). Table S3: Genotypic variability in tiller number of plants grown under various $\mathrm{K}^{+}$supply. Data are mean $\pm \mathrm{SE}(n=6)$. Genotypes have been divided into three group according to cluster analysis (see Section 3.1 and Figure 1). Table S4: Genotypic variability in spike number of plants grown under various $\mathrm{K}^{+}$supply. Data are mean $\pm \mathrm{SE}(n=6)$. Genotypes have been divided into three group according to cluster analysis (see Section 3.1 and Figure 1).

Author Contributions: Conceptualization, S.S., T.A. and M.Z.; methodology, L.S. and M.B.G.; formal analysis, W.A.A., F.F. and M.B.G.; investigation, W.A.A.; resources, M.Y.; data curation, W.A.A.; writing-M.B.G. and S.S.; revision and editing-S.S., T.A., M.Z. and L.S.; supervision, S.S., T.A., M.Z. and L.S.; project administration, M.Y.; funding acquisition, S.S., M.Z. and M.Y. All authors have read and agreed to the published version of the manuscript.

Funding: This work was supported by Grain Research and Development Corporation grant to S.S. and M.Z. S.S. acknowledges funding from National Natural Science Foundation of China (project 31870249) and the National Distinguished Expert Project (WQ20174400441).

Institutional Review Board Statement: Not applicable.

Informed Consent Statement: Not applicable.

Data Availability Statement: Not applicable.

Conflicts of Interest: The authors declare no conflict of interest.

\section{References}

1. Adams, E.; Shin, R. Transport, signaling, and homeostasis of potassium and sodium in plants. J. Integr. Plant Biol. 2014, 56, 231-249. [CrossRef]

2. Hermans, C.; Hammond, J.P.; White, P.J.; Verbruggen, N. How do plants respond to nutrient shortage by biomass allocation? Trends Plant Sci. 2006, 11, 610-617. [CrossRef]

3. Amtmann, A.; Hammond, J.P.; Armengaud, P.; White, P.J. Nutrient sensing and signalling in plants: Potassium and phosphorus. Adv. Bot. Res. 2005, 43, 209-257.

4. Hawkesford, M.; Horst, W.; Kichey, T.; Lambers, H.; Schjoerring, J.; Møller, I.S.; White, P. Functions of macronutrients. In Marschner's Mineral Nutrition of Higher Plants, 3rd ed.; Marschner, P., Ed.; Academic Press: Walthan, MA, USA, 2011 ; pp. 135-151.

5. White, P.; Karley, A. Potassium. In Cell Biology of Metals and Nutrients; Hell, R., Mendel, R.R., Eds.; Springer: Berlin/Heidelberg, Germany, 2010; pp. 199-224.

6. Pettigrew, W.T. Potassium influences on yield and quality production for maize, wheat, soybean and cotton. Physiol. Plant. 2008, 133, 670-681. [CrossRef] 
7. Besford, R.; Maw, G. Effect of potassium nutrition on tomato plant growth and fruit development. Plant Soil 1975, 42, 395-412. [CrossRef]

8. Leigh, R.A.; Wyn Jones, R. A hypothesis relating critical potassium concentrations for growth to the distribution and functions of this ion in the plant cell. New Phytol. 1984, 97, 1-13. [CrossRef]

9. Zörb, C.; Senbayram, M.; Peiter, E. Potassium in agriculture-status and perspectives. J. Plant Physiol. 2014, 171, 656-669. [CrossRef]

10. Lal, R. Soil management in the developing countries. Soil Sci. 2000, 165, 57-72. [CrossRef]

11. Römheld, V.; Kirkby, E.A. Research on potassium in agriculture: Needs and prospects. Plant Soil 2010, 335, 155-180. [CrossRef]

12. Moore, L.V.; Dodd, K.W.; Thompson, F.E.; Grimm, K.A.; Kim, S.A.; Scanlon, K.S. Using behavioral risk factor surveillance system data to estimate the percentage of the population meeting US Department of Agriculture food patterns fruit and vegetable intake recommendations. Am. J. Epidemiol. 2015, 181, 979-988. [CrossRef]

13. Pettigrew, W.; Meredith, W., Jr. Dry matter production, nutrient uptake, and growth of cotton as affected by potassium fertilization. J. Plant Nutr. 1997, 20, 531-548. [CrossRef]

14. Rengel, Z.; Damon, P.M. Crops and genotypes differ in efficiency of potassium uptake and use. Physiol. Plant. 2008, 133, 624-636. [CrossRef] [PubMed]

15. Prajapati, K.; Modi, H. The importance of potassium in plant growth-A review. Indian J. Plant Sci. 2012, 1, 177-186.

16. Mengel, K. Impact of potassium on crop yield and quality with regard to economical and ecological aspects. In Food Security in the WANA Region: The Essential Need for Balanced Fertilization; Johnston, A.E., Ed.; International Potash Institute: Basel, Switzerland, 1997; pp. 157-174.

17. Fageria, N.; Melo, L. Agronomic evaluation of dry bean genotypes for potassium use efficiency. J. Plant Nutr. 2014, 37, 1899-1912. [CrossRef]

18. White, P.; Hammond, J.; King, G.; Bowen, H.; Hayden, R.; Meacham, M.; Spracklen, W.; Broadley, M. Genetic analysis of potassium use efficiency in Brassica oleracea. Ann. Bot. 2010, 105, 1199-1210. [CrossRef] [PubMed]

19. Yashveer, S.; Singh, V.; Kaswan, V.; Kaushik, A.; Tokas, J. Green biotechnology, nanotechnology and bio-fortification: Perspectives on novel environment-friendly crop improvement strategies. Biotechnol. Genet. Eng. Rev. 2014, 30, 113-126. [CrossRef] [PubMed]

20. Rengel, Z.; Marschner, P. Nutrient availability and management in the rhizosphere: Exploiting genotypic differences. New Phytol. 2005, 168, 305-312. [CrossRef]

21. Yadav, R.; Courtois, B.; Huang, N.; McLaren, G. Mapping genes controlling root morphology and root distribution in a doubledhaploid population of rice. Theor. Appl. Genet. 1997, 94, 619-632. [CrossRef]

22. Baligar, V.; Fageria, N.; He, Z. Nutrient use efficiency in plants. Commun. Soil Sci. Plant Anal. 2001, 32, 921-950. [CrossRef]

23. Tehulie, N.; Eskezia, H. Effects of Nitrogen Fertilizer Rates on Growth, Yield Components and Yield of Food Barley (Hordeum vulgare L.): A Review. J. Plant Sci. Agric. Res. 2021, 5, 46.

24. Degl'Innocenti, E.; Hafsi, C.; Guidi, L.; Navari-Izzo, F. The effect of salinity on photosynthetic activity in potassium-deficient barley species. J. Plant Physiol. 2009, 166, 1968-1981. [CrossRef] [PubMed]

25. Schmidt, S.B.; George, T.S.; Brown, L.K.; Booth, A.; Wishart, J.; Hedley, P.E.; Martin, P.; Russell, J.; Husted, S. Ancient barley landraces adapted to marginal soils demonstrate exceptional tolerance to manganese limitation. Ann. Bot. 2019, 123, 831-843. [CrossRef]

26. Zhang, H.; Wang, X.; You, M.; Liu, C. Water-yield relations and water-use efficiency of winter wheat in the North China Plain. Irrig. Sci. 1999, 19, 37-45. [CrossRef]

27. Damon, P.M.; Rengel, Z. Wheat genotypes differ in potassium efficiency under glasshouse and field conditions. Aust. J. Agric. Resour. Econ. 2007, 58, 816-825. [CrossRef]

28. Yang, Z.; Sun, X.; Wang, S.; Zhang, Q. Genetic and physical mapping of a new gene for bacterial blight resistance in rice. Theor. Appl. Genet. 2003, 106, 1467-1472. [CrossRef]

29. Parzies, H.; Spoor, W.; Ennos, R. Genetic diversity of barley landrace accessions (Hordeum vulgare ssp. vulgare) conserved for different lengths of time in ex situ gene banks. Heredity 2000, 84, 476-486. [CrossRef] [PubMed]

30. Alemu, A.; Feyissa, T.; Letta, T.; Abeyo, B. Genetic diversity and population structure analysis based on the high density SNP markers in Ethiopian durum wheat (Triticum turgidum ssp. durum). BMC Genet. 2020, 21, 18. [CrossRef] [PubMed]

31. Amtmann, A.; Blatt, M.R. Regulation of macronutrient transport. New Phytol. 2009, 181, 35-52. [CrossRef]

32. Erbs, M.; Manderscheid, R.; Jansen, G.; Seddig, S.; Pacholski, A.; Weigel, H.-J. Effects of free-air $\mathrm{CO}_{2}$ enrichment and nitrogen supply on grain quality parameters and elemental composition of wheat and barley grown in a crop rotation. Agr. Ecosyst. Environ. 2010, 136, 59-68. [CrossRef]

33. Talbi Zribi, O.; Abdelly, C.; Debez, A. Interactive effects of salinity and phosphorus availability on growth, water relations, nutritional status and photosynthetic activity of barley (Hordeum vulgare L.). Plant Biol. 2011, 13, 872-880. [CrossRef] [PubMed]

34. Zeng, J.; Quan, X.; He, X.; Cai, S.; Ye, Z.; Chen, G.; Zhang, G. Root and leaf metabolite profiles analysis reveals the adaptive strategies to low potassium stress in barley. BMC Plant Biol. 2018, 18, 187. [CrossRef] [PubMed]

35. Parent, B.; Tardieu, F. Temperature responses of developmental processes have not been affected by breeding in different ecological areas for 17 crop species. New Phytol. 2012, 194, 760-774. [CrossRef] [PubMed] 
36. Zeng, F.; Konnerup, D.; Shabala, L.; Zhou, M.; Colmer, T.D.; Zhang, G.; Shabala, S. Linking oxygen availability with membrane potential maintenance and $\mathrm{K}^{+}$retention of barley roots: Implications for waterlogging stress tolerance. Plant Cell Environ. 2014, 37, 2325-2338. [CrossRef] [PubMed]

37. Ramamoorthy, P.; Lakshmanan, K.; Upadhyaya, H.D.; Vadez, V.; Varshney, R.K. Shoot traits and their relevance in terminal drought tolerance of chickpea (Cicer arietinum L.). Field Crops Res. 2016, 197, 10-27. [CrossRef]

38. Ahanger, M.A.; Agarwal, R. Salinity stress induced alterations in antioxidant metabolism and nitrogen assimilation in wheat (Triticum aestivum L) as influenced by potassium supplementation. Plant Physiol. Biochem. 2017, 115, 449-460. [CrossRef]

39. Amanullah, I.A.; Irfanullah, H. Potassium management for improving growth and grain yield of maize (Zea mays L.) under moisture stress condition. Sci. Rep. 2016, 6, 34627. [CrossRef] 